University of Minnesota Morris Digital Well

University of Minnesota Morris Digital Well

English Publications

Faculty and Staff Scholarship

Summer 2011

\title{
Imperial Boyhood: Piracy and the Play Ethic
}

Bradley Deane

University of Minnesota - Morris, deaneb@morris.umn.edu

Follow this and additional works at: https://digitalcommons.morris.umn.edu/eng_facpubs

Part of the Literature in English, British Isles Commons

\section{Recommended Citation}

Deane, Bradley. "Imperial Boyhood: Piracy and the Play Ethic." Victorian Studies 53, no. 4 (Summer 2011): 689-714.

This Article is brought to you for free and open access by the Faculty and Staff Scholarship at University of Minnesota Morris Digital Well. It has been accepted for inclusion in English Publications by an authorized administrator of University of Minnesota Morris Digital Well. For more information, please contact skulann@morris.umn.edu. 


\title{
Imperial Boyhood: Piracy and the Play Ethic
}

\author{
BRADLEY DEANE
}

11 children, except imperialists, grow up. Such, at least, seems
the lesson of late Victorian Britain, when an ideal of boyish-
ness that never faded came to be as admired as that of an empire on which the sun never set. Among the most venerable heroes of the empire we find many ostentatiously boyish men: Robert BadenPowell, who saw the empire's future in the hands of his boy scouts and was praised for having "always been a boy himself" ("B-P"); Alfred Milner in South Africa, who called his circle of disciples the "kindergarten"; and Horatio Kitchener in Egypt, who called his the "band of boys." When, in his late forties, Cecil Rhodes exulted, "I am a boy! I am a boy! Of course I shall never get old!" (Menpes 105), he anticipated by several years the first performance of J. M. Barrie's Peter Pan; or, The Boy Who Wouldn't Grow Up (1904). This remarkable rebellion against masculine maturity enlisted writers, too, such as Rudyard Kipling, whom E. M. Forster in an essay of the same name called the "Boy Who Never Grew Up," and Joseph Conrad, who warned, "I am not going to discard the beliefs of my boyhood for anybody on earth" (Set ix). Reimagined in the pages of imperial romance, the frontier became crowded with youthful men and heroic adolescents, while the novels themselves were increasingly aimed at a male audience whose age was explicitly blurred: after the success of Treasure Island (1883), as Harvey Darton has argued, previously distinct readerships of men and boys found common ground

Aвstract: Representations of perpetual boyhood came to fascinate the late Victorians, partly because such images could naturalize a new spirit of imperial aggression and new policies of preserving power. This article traces the emergence of this fantasy through a series of stories about the relationship of the boy and the pirate, figures whose opposition in mid-Victorian literature was used to articulate the moral legitimacy of colonialism, but who became doubles rather than antitheses in later novels, such as R. L. Stevenson's Treasure Island and Joseph Conrad's Lord Jim. Masculine worth needed no longer to be measured by reference to transcendent, universal laws, but by a morally flexible ethic of competitive play, one that bound together boyishness and piracy in a satisfying game of international adventure. 
in adventure stories. H. Rider Haggard's King Solomon's Mines (1885) was dedicated "to all the big and little boys who read it" (37), just as Arthur Conan Doyle's The Lost World (1912) addressed itself "To the boy who's half a man / And the man who's half a boy" (ii). By the late Victorian period, it had long been the case that, as Joseph Bristow writes, "Empire and Boyhood ... were mutually supportive" (41), but the rejection of masculine maturation represents a distinctive response to the period's new imperial ideologies. For the mid-Victorians, by contrast, boys had to grow up in order to fulfill their ideological role in the grand narratives of empire. Stories of boys' adventures abroad had been, as Jacqueline Rose has put it, "inheritors of a fully colonialist concept of development" (57): their boy heroes learned in the school of empire how to master their instincts and, by externalizing this trajectory of self-discipline, how to control territories and subdue natives. The development of the child thus recapitulated the central metanarratives of liberal imperialism: the civilizing mission, the enlightenment of the heathen, and the march of progress. But how do we interpret the imperial politics of the boys who wouldn't grow up?

Scholars have diagnosed persistent boyhood as a byproduct of ideological faultlines widened by the political paradoxes of colonial experience; whether characterizing it as "atrophic adolescence" (Suleri 113) or "frozen youth" (Esty 423), scholars often regard it as an ideological crisis expressed through an aesthetic muddle. But perpetual boyhood also had an immense appeal as a fantasy that enabled and sustained the new imperialist imagination. By the turn of the century, British boyhood was subject to the same intensity of revision as the British imperial mission. For instance, boys were increasingly represented as plucky and clever but also largely amoral and often cruel, or as Barrie put it in Peter and Wendy (1911), "gay and innocent and heartless" (226). I argue that an image of perpetual boyhood grounded in such qualities supported and naturalized the adventurous realpolitik of the new imperialism. As conservative strains of imperialism displaced older liberal narratives of progress, civilization, and enlightenment in favor of militarism, expansionism, and a vision of permanent dominion and endless competition, imperialists found in enduring boyishness a natural and suitably anti-developmental model of identity. An empire that had ceased to strive towards idealistic ends no longer required its heroes to grow up, and a non-developmental understanding of global politics welcomed a masculinity resistant to development. 
In its theory and practice, if only partly in its rhetoric, the late nineteenth century's dominant strain of imperialism owed more to the often cynical pragmatism of Benjamin Disraeli and Robert Cecil (Lord Salisbury) than to the grand narratives of the liberal tradition that had animated Thomas Babington Macaulay, James and J. S. Mill, and William Gladstone. As J. A. Hobson lamented in 1902, the "old Liberal notion" of empire had been "discredited, and survive[d] only for platform purposes" (102). Hannah Arendt has argued that, having made expansion a goal of empire rather than just its means, the new imperialists cast aside the liberal telos of universal progress through the diffusion of European principles and institutions. Formerly the would-be schoolmaster or proselytizer to the world, the British conqueror "became an administrator who no longer believed in the universal validity of law" (221). But as Daniel Bivona reminds us in his extension of Arendt's argument, the late-Victorian bureaucratization of empire required compensatory images of individual heroism (18): just as the empire needed anonymous functionaries, the imperial imagination demanded charismatic figures of unconquerable spirit. One of the most crucial characters with which popular fiction fed this desire, I argue, was the figure of the boy who wouldn't grow up. Persistent boyishness put a more beguiling face on the new imperialist ideology Arendt and Bivona describe, transforming aimless process into endless adventure and the absence of universal law into a profusion of possibilities for exhilarating play.

Victorian discussions of play reveal a wide range of attitudes and assumptions. ${ }^{1}$ Still, it is possible to identify late-nineteenth-century trends in the conceptualization of child's play that suggest reasons for the appeal of perpetual boyhood among imperialists. As the end of the century approached, childhood play was liberated from the judgments of evangelical and utilitarian traditions that regarded it as merely frivolous or even morally corrupting. Newer ideas, such as those championed by the growing Kindergarten movement or, later, the theories of Karl Groos and Caldwell Cook, dignified play as the free and healthy expression of the essence of childhood. Educational theory allowed that the impulses of play might be directed toward productive ends, but only insofar as this direction preserved pleasure and subordinated the ends of work to the spirit of play. ${ }^{2}$ But play was also increasingly valued for its own sake. As childhood play was exempted from the restraints of religious morality or civic duty, it was also widely accepted as fundamentally competitive, especially for boys 
(see Nadel 32). Herbert Spencer thus claimed that "the sports of boys, chasing one another, wrestling, making prisoners, obviously gratify in a partial way the predatory instincts. ... No matter what the game, the satisfaction is in achieving victory, in getting the better of an antagonist" (631). This valorization of play as a natural activity valued for its own pleasures and beauties rather than its subservience to external imperatives was easily reconcilable with a ruthless new imperialism that had largely abandoned the restrictive principles of its liberal predecessors. The self-justifying pursuit of perpetual empire could be naturalized and ennobled in a character like Kipling's Kim, who "love[s] . . the game for its own sake" (51), even as he comes to understand colonial domination as an extension of his boyish play.

The combination of new imperialist politics and the romance of endless boyhood produced a distinctive set of interlocking values of male behavior that I will call the imperial play ethic. I have derived this model of play principally from patterns in the representation of masculine activity in late-Victorian popular fiction, though, as the rhetoric of Rhodes and other imperial administrators hints, its assumptions were not confined to literature. By contrast with the athletic "games ethic" inspired by muscular Christianity in the $1850 \mathrm{~s}$, which held that the disciplined body was an outward expression of moral character, the imperial play ethic I describe placed no particular importance on physicality or on the mission of moral character building that, as J. A. Mangan has shown, was central to the games ethic. While the play ethic might include sport, moreover, it also encompassed other ludic forms, such as games of chance or imaginative role-play. Its locus was the playground, where boys could spontaneously invent any number of games, rather than the regimented playing field. I do not suggest that there are essential disparities between the categories of playing, gaming, and sporting (even though some Victorians drew such distinctions). Rather, the key contrast follows from different attitudes with which those activities were valued. The play ethic prized the ostensibly natural impulses of boys and sought to preserve them rather than force them to submit to the external order of moral maturity. It was concerned with questions of fairness that might guide the players in a game, but generally uninterested in questions of a universal justice that might guide us all.

The imperial play ethic emerges from the combination of several elements that, taken together, distinguish it from other contemporary logics of play. First, as I have suggested, it was non-developmental: 
it assumed that boys or boyish men were equipped naturally for struggle on the frontier, and that a boyish spirit was so well-suited for the great game of empire that any deviation from it could be crippling. Second, it was situational: each imperial encounter was a new game to be played by locally generated rules rather than by deference to universal moral strictures. Third, it was self-consciously performative: play required great attention to one's appearance to other players-friend and foe alikeemphasizing role-playing and conduct over interiority, and the forms of competition over its transcendent meaning. Lastly, and correlatively, play was regulated primarily by shame: in its emphasis on external opinions, the play ethic depended less on the inward sanctions of guilt than on the dishonor that followed from failure in the eyes of others.

The play ethic found particularly rich expression in stories that featured another key figure of the new imperialist imagination: the pirate. Pirates are powerfully linked to boyhood in the Victorian imagination, not only because playing at pirates was a common boyhood game, but also because of piracy's prominence in boys' reading and, after Treasure Island, in the adventure fiction aimed at the synthesized man-boy readership. Frequently pairing pirates and boys, these stories allow us to trace new implications of boyhood as well as the changing ethics of imperialism. Pirates who in mid-century fiction had clashed with the virtuous youth of England began to look less like the heroes' foils than their doubles, partners, or secret sharers. By the end of the century pirates could be heroes themselves-not simply in the mold of the misunderstood but noble corsairs of the romantic era, but as cynical, amoral, brutal adventurers. Cutcliffe Hyne, for instance, achieved enormous popular success in the 1890 s with his recurring character Captain Kettle, a self-proclaimed brute who sells his violent talents to whoever offers the most money. In 1915, Russell Thorndike published his first novel about Dr. Syn, a beloved English vicar and smuggler who had previously won notoriety as the vicious pirate Captain Clegg. The same year also saw the first of Rafael Sabatini's bestselling historical swashbucklers, The Sea Hawk, in which an English knight becomes the Muslim leader of a crew of Arab pirates under the name Sakr-el-Bahr. These colorful examples suggest the extent to which heroic piracy had seized the imagination of popular audiences, even at the expense of undermining the bulwarks of liberal imperialism, including free trade, Christianity, and Englishness. But this essay will be chiefly concerned with two more familiar pirate stories. 
The first is Treasure Island, which marks a pivotal moment in the lateVictorian representation of piracy and illustrates Stevenson's use of the amoral pirate as a figure around which the fantasies of boyish play coalesce. The second is Conrad's Lord Jim (1900), which, almost twenty years later, speaks to the enduring appeal of Stevenson's dream while revealing the complications and anxieties produced by this construction of imperial masculinity.

\section{Piracy, Boyhood, and Empire before Stevenson}

Every empire produces its own pirates, redefining the criminals of the sea in order to assert, by contrast, the legitimacy of its own overseas adventures. The Roman Empire called pirates hostes humani generis"enemies of all humanity"-who lived entirely outside the laws of nations or morality. As Marcus Rediker has observed, "the term pirate has been highly ideological from antiquity forward, functioning more or less as the maritime equivalent of barbarian - that is, anyone who was an enemy of the Romans. No matter who or what he actually was, the pirate was reduced to a criminal pure and simple, the very negation of imperial social order" (174). Rediker's generalization captures the essential ideological function of pirate stories of the mid-Victorian period, but it applies less convincingly to the last decades of the century, the very time at which the proliferation of pirate fiction reveals the urgency of the cultural work the pirate was called on to perform.

In mid-century fiction, pirates indeed serve as the foils of all that is decent, Christian, and British. When Charles Dickens responded to the "Indian Mutiny" with his chillingly propagandistic "The Perils of Certain English Prisoners" (1857), he recasts the Indian sepoys as an international gang of "barbarous Pirates" whom he vigorously condemns as the "scum of all nations ... the worst men in the world picked out from the worst" (237). Against them stand the brave and upright Englishmen of the Royal Navy, who, as they claim, "hold [their] commission by the allowance of God" and who intend to use it "to exterminate these people from the face of the earth" (213). Dickens represents pirates in so profound an opposition to English virtue that only aggressively Manichean distinctions can capture it. Other stories of the 1850 s made a similar case, particularly those in the emerging group of respectable boys' novels, such as William Kingston's The Pirate of the Mediterranean (1851), Charles Kingsley's Westward Ho! (1855), and 
R. M. Ballantyne's The Coral Island (1857), which use piracy as the test by which an inherently moral British boyhood could be confirmed.

In Charles Stevens's Jack Rushton; or, Alone in the Pirates' Lair (1866-67), the serial story that opened the first number of Boys of England, we find an overtly moralizing treatment of the boy-pirate relationship. Stevens's story pits his fourteen-year-old hero Jack against an international "motley crew" of "villainous-looking" pirates (2-3). Jack is paired with a pirate called Ambrose, who recognizes in Jack his own youth and ultimately confesses the story of his departure from his respectable beginnings. As Bristow has argued, Stevens's story sets Jack against Ambrose as a foil, insisting on their moral opposition even while acknowledging that the boy and the pirate will each in his own way appeal to impressionable readers (36-37). As in Ballantyne's The Coral Island, which deploys a similar logic, Stevens's boy hero's maturing confidence and power depends on the pirate's trajectory toward ethical reformation, which in turn mirrors the civilization of the savage. The three narrativse threads interweave in a story that entwines the maturation of the moral British subject with the progressive and enlightening mission of empire. This is the kind of novel from which Stevenson's Treasure Island would signal a profound departure, one that rent the barriers of law and Christianity that had stood between the boy and his piratical antagonist, and that offered instead an integrative play ethic through which the two could, after all, easily fit together.

\section{Treasure Island: A Furlough from the Moral Law}

Treasure Island begins with the pirate Billy Bones taking up residence at the inn run by young Jim Hawkins's family, an opening with which Stevenson brings piracy home to England. While Jim's father timidly worries that Billy's domination of the barroom will scare away customers, Jim concludes that "his presence did us good. People were frightened at the time, but on looking back they rather liked it; it was fine excitement in a quiet country life; and there was even a party of the younger men who pretended to admire him, calling him a 'true sea-dog,' and a 'real old salt,' and such like names, and saying there was the sort of man that made England terrible at sea" (5-6). This passage suggests that the appeal of the pirate extends to the national self-image, so that the satisfaction the young men take in England's "terrible" naval power is undiminished by its association with the lawless violence of piracy. The 
sentiment is reiterated when Squire Trelawney admits that the bloodthirstiness of Billy's former leader, the murderous Captain Flint, sometimes made Trelawney proud that Flint "was an Englishman" (31). And just as Englishness becomes implicated in piracy, the pirates cease to function as the wicked counterweights of all that is decent and Christian. The heroes are quick to behave piratically, while the pirates-particularly their leader, Long John Silver-act out a parody of conventional middle-class rectitude. ${ }^{3}$ From its outset, in short, Treasure Island blurs distinctions on which the ideological work of respectable pirate stories had depended.

This turn was recognized by the novel's first critics, such as the reviewer from the Dial, who wrote that the novel "will be relished by adventure-loving boys, but whether it will be wholesome reading for them is more than doubtful" (Maixner 142). Critics since have commented on the novel's striking amorality, as we find in Diane Simmons's argument that the story unfolds in a "moral duty-free zone" characterized by a "fruitful, and in the last analysis, non-judgmental coexistence between good and evil" $(46,47)$. Kevin Carpenter goes further, identifying Stevenson's work as a watershed that "helped to make children's fiction without an underlying moral purpose widely acceptable" (90). Still, in place of the moral lessons that traditionally followed from the clash of Englishmen and pirates, Stevenson offers what amounts to an alternative ethical code, one that frames the characters' incessant judgments of one another and of themselves, and one which sets the terms in which masculinity can be defined. The alternative code depends on the novel's erosion of yet another traditional distinction, the opposition of the boy and the pirate.

For Stevenson, the figure of the pirate exemplifies the persistence of boyhood, as he illustrates both in and out of Treasure Island. In an essay in Virginibus Puerisque (1881), Stevenson reflects on a passage in Mark Twain's Adventures of Tom Sawyer (1876) in which Tom and Huck have taken to playing pirates and become absurdly confused about the morality of their roles, pledging that "so long as they remained in that business, their piracies should not again be sullied with the crime of stealing." But for Stevenson, the would-be pirates' comic moral confusion offers a glimpse into the quintessence of boyhood: "Here we recognise the thoughts of our boyhood; and our boyhood ceased-well, when?-not, I think, at twenty; nor, perhaps, altogether at twenty-five; nor yet at thirty; and possibly, to be quite 
frank, we are still in the thick of that arcadian period" (24). The piratical boy, morally dubious though he may be, represents to Stevenson an ideal of never-ending youth. For those men who have outgrown the ideal, on the other hand, Stevenson reserves a special scorn. Thus when William Monkhouse, author of A Dream of Idleness (1865), expressed his fondness for repose, Stevenson privately rebuked him for indulging a self-satisfied bourgeois complacency:

\footnotetext{
When a man, seemingly sane, tells me he has "fallen in love with stagnation," I can only say to him, "You will never be a Pirate!" This may not cause any regret to Mrs. Monkhouse; but in your own soul it will clang hollow-think of it! Never! After all boyhood's aspirations and youth's immoral day-dreams... is there not some escape, some furlough from the Moral Law, some holiday jaunt contrivable into a Better Land? Shall we never shed blood? (Letters 365)
}

The literary pairing of boys and pirates here assumes a new function: to naturalize the behavior of pirates as an expression of the essence of boyhood. Stevenson's own attitudes toward imperialism are too complex to summarize neatly, but his cultural influence through Treasure Island was to remap the imperial frontier as a self-sufficient playground, not a place on which the moral laws of Britain are impressed, but as the kind of "Better Land" in which they can be escaped.

Stevenson's essays on childhood and child's play, published just before the completion of Treasure Island, represent childhood as an immoral or pre-moral time, and we can see how jarringly he breaks from the romantic notion of childhood purity when he describes children as "pretty like flowers and innocent like dogs" (Virginibus 224). But while they may be innocent only in the sense that dogs are-obliviously untouched by moral problems-Stevenson's children are also shrewd, imaginative, and keenly perceptive. They differ from adults in absorbing the elements of the world they see into a detached model of that world, a reflected space in which the value of their actions is judged only by the internal rules of their closed system and not by the moral consequences that they have left, as it were, on the distant shores of the mundane. This is the essence of what Stevenson calls "play":

Two children playing at soldiers are far more interesting to each other than one of the scarlet beings whom they are both busy imitating. This is perhaps the greatest oddity of all. "Art for art" is their motto; and the doings of grown folk are only interesting as the raw material for play. Not Theophile Gautier, not Flaubert, can look more callously upon life, or rate the reproduction more highly over the 
reality; and they will parody an execution, a deathbed, or a funeral . . with all the cheerfulness in the world. (215)

Stevenson's callous children are less concerned with human sympathy and its moral corollaries than with elaborating rules of their own, rules that might be spontaneously generated around even the most trivial pretext: "What wonderful fancies I have heard evolved out of the pattern upon tea-cups! - from which there followed a code of rules and a whole world of excitement, until tea-drinking began to take rank as a game" (217-18).

This absorption with the rules of play replaces conventional moralizing in Treasure Island. The pirates themselves, while thoroughly lawless from the perspective of British authority, are in fact obsessed with their own set of rules. The most memorable token in their piratical game is the black spot; the one presented to Billy Bones early in the novel is a simple "round of paper," colored black on one side and bearing on the other, "in a very good, clear hand, this short message: 'You have till ten to-night" (22). The formal ceremony of this warning and the evident care of its penmanship imply the importance of the code that governs piracy, to which the pirates adhere even at the expense of self-interest. When a black spot is later presented to Long John Silver during the scene of a pirate council, we admire his cleverness at maneuvering within the code. The confrontation between Silver and his dissatisfied henchmen emphasizes the reliance of both sides on a rhetoric of rules: Silver's underlings first demand the right to challenge his authority "according to rules" (156), and they then present him with a black spot signaling their intention to depose him. Silver responds by complimenting his chief challenger, George Merry, on his grasp of the system, saying, "You always was brisk for business, and has the rules by heart, George, as I'm pleased to see" (159). But when George assumes the matter is settled, Silver turns the tables with a masterful riposte: "I thought you said you knowed the rules,' returned Silver, contemptuously. 'Leastways if you don't, I do; and I wait here-and I'm still your cap'n, mind-till you outs with your grievances, and I reply; in the meantime your black spot ain't worth a biscuit" (159). Silver's ensuing defense of his authority is his finest hour, a pivotal moment that decides the fortunes of everyone on the island. Stevenson's fascination with the pirates' rules is in no way diminished by their independence from any overarching morality, just as Silver's charisma in this scene is not undercut by his plans to betray the 
very men whom he has just convinced to reaffirm his leadership. Rather, the allure of the rules lies in their freedom from any constraints beyond a bare scaffold of regulations that allow conflicts to be experienced as exciting contests of skill and imagination, precisely in the way that Stevenson conceives of the appeal of children's play. It is in this sense that Jim, forced into a fragile alliance with a man he knows to be a murderer and traitor, can nevertheless admire Silver's talent in playing a "remarkable game" (162-63).

The play ethic pervades the novel, casting the protagonists and their adversaries as two teams competing for the same prize. Their game accommodates horror and brutality, and its score is kept by counting the lives of the remaining players. When Jim is given the chance to score a kill of his own, the scene emphasizes both the continuity between pirates and boys and the subversion of Christian moralizing by the play ethic. The episode takes place when Jim slips aboard the Hispaniola and confronts the wounded pirate Israel Hands. Jim's clash with Israel begins, just as Ballantyne or Stevens might have written it, with Jim's advice that the wounded pirate should look to the state of his immortal soul and fall to his prayers "like a Christian man" (138). But the exchange that follows is more parody of Ballantyne than homage. Jim instructs the pirate Hands to pray for forgiveness while thinking about "the bloody dirk he had hidden in his pocket"; the pirate in turn solemnly declares, "Well, now I tell you, I never seen good come o' goodness yet. Him as strikes first is my fancy; dead men don't bite; them's my views-amen, so be it" (138).

If we are initially puzzled by Jim's sudden concern for the spiritual well-being of the pirates-which, after all, never troubles him before or after this moment-we quickly learn his real motives are his fear of that "bloody dirk" and his hope that he might persuade Israel to give it up. Jim, in other words, is as cynically pragmatic as his opponent, and when he manages to train a gun on the pirate, he leaves off moralizing and echoes the pirate's blasphemous prayer: "One more step, Mr. Hands . . . and I'll blow your brains out! Dead men don't bite, you know,' I added, with a chuckle" (142).

The struggle between Jim and Israel exemplifies the novel's representation of adventurous conflict and illustrates the tools required for success: resourcefulness, skill, trickery, bravery, panache, and luck. And these virtues follow naturally from Jim's undeveloped boyish instincts. In the end, his match against Israel is a familiar game: "It was 
such a game as I had often played at home about the rocks of Black Hill Cove; but never before, you may be sure, with such a wildly beating heart as now. Still, as I say, it was a boy's game, and I thought I could hold my own at it" (141). Stevenson is less interested in differentiating the two characters than in emphasizing their mutual facility in this deadly game. On the level field of the play ethic there is no moral high ground, only a perch atop the ship's mast from which Jim blows out Israel's brains.

In Treasure Island, the play ethic allows a struggle for life to be experienced also as a game of masculine self-fashioning. The characters offer running commentaries on which of the men have shown themselves truly to be men, generally by measuring themselves against one another: Livesey calls Captain Smollett "a better man than I am" (102); Silver declares his right to command because he is "the best man by a long sea-mile" (155) and a "better man" than George Merry (162), while Jim affirms that Silver is "twice the man" that the other pirates are (166); and Silver himself has "never seen a better man" than Livesey (167). One does not so much grow into manhood as strive constantly for a better manhood than one's rivals. In fact, one need not be a man in the developmental sense to be a man in the competitive sense. Young Jim, for instance, proves himself when he openly shames the pirates who have captured him, concealing his terror and gloating over his victories against them. His performance is rewarded with Silver's acclaim: "I've never seen a better boy than that. He's more a man than any pair of rats of you" (155). If boys can be men-even better men-in Treasure Island, it is because the rules of play that Stevenson uses to measure manhood are derived from the games for which he imagines boys are inherently suited.

"Inside the play-ground," writes Johan Huizinga, play "creates order, $i$ s order. Into the confusion of life it brings a temporary, a limited perfection" (10). Huizinga's insight suggests the attraction of the play ethic to both men and boys. The playground offers intense feelings of freedom from the restrictions of convention, of a rule-based orderliness that renders actions perfectly intelligible. But the playground is also a space of recognition, of the ostentatious performance of one's own masculinity before other men. It is a theater of character in which each boy is both actor and witness, as indicated in an anonymous Victorian book called Boys and Their Ways (1880):

It is in the playground, I repeat, that the boy shows himself what he really is.... There it is that a boy, if he has any genuine stuff in him, reveals it; and there it is that keen eyes detect it or the want of it. For boys ... soon take the measure of 
their companions; they learn to appraise them at their exact value, and it is specially in the playground that this critical faculty bears fruit. (90)

Skeleton Island is just such a playground, divorced from the ordinary world and its ordinary values, where male communities can regard and police themselves according to their own rules. It enables, as Huizinga writes, "the feeling of being 'apart together' in an exceptional situation, of sharing something important, of mutually withdrawing from the rest of the world and rejecting the usual norms" (12). In this way Stevenson's island would become the model of many other playgrounds that followed: Haggard's Kukuanaland, Kipling's Kaffiristan, Doyle's Maple-White Land, and Barrie's Neverland.

Just as Treasure Island mapped out exotic new playgrounds, it launched an armada of pirates who commanded the pages of popular fiction aimed at both boys and men, pirates whose bloodthirsty criminality is mitigated by their admirable audacity and cleverness: to the ranks of Captain Kettle, Dr. Syn, and Sakr-el-Bahr we can add, for instance, Max Pemberton's Captain Black (1893) and Doyle's Captain Sharkey (1900). ${ }^{4}$ But this proliferation of imaginary pirates occurred in concert with an increasing willingness to embrace Britain's piratical heritage as the root of its modern imperial identity, especially by reclaiming the Elizabethan privateers as national icons. Of these, the vicious slaver Francis Drake fared particularly well, becoming the hero of the poet Alfred Noyse's Drake: An English Epic (1908) - which celebrated him as "the boyish privateer" (12) - and Louis Parker's Drake: A Pageant Play (1912). Pirates also made their way into jingoist histories aimed at children, most tellingly in George Griffith's Men Who Have Made the Empire (1897), which regarded even William the Conqueror as a pirate. "If we have successfully cleared our minds of cant," Griffith writes, "we shall see plainly that, since all nations begin in piracy of some sort, it is natural to expect that the best pirates will be the best Empire-Makers. That old strain is, happily, not yet extinguished" (6). If the piratical strain is not yet vanished from the national character, it might also be preserved in the individual men who, steadfastly maintaining their boyish ability to play outside the bounds of moral cant, could fit themselves for (as Disraeli famously put it) the maintenance of empire. The piratical boy had changed spectacularly since mid-century novelists treated him as a moral menace. He could now be reconceived as a hero whose evergreen boyishness signaled the tenacious endurance of the empire. 


\section{Lord Jim: The Problem of Shame}

Cast loose on a playground, the boy of late-Victorian imperial romance would be spared much of the grueling work of moral maturation that had beset his mid-Victorian counterparts from Thomas Hughes's Tom Brown to Dickens's Pip. As the developmental narrative of the bildungsroman was displaced by the episodic adventure tale, the decisive question of successful manliness was no longer moral growth but conduct in a limitless series of competitive trials. The agonistic shift simplified the meaning of success, but also introduced psychic costs of its own, largely because the externalization of the struggle of identity implied that the individual male was no longer the privileged reader of his own story. Stevenson hints at this anxiety when Dr. Livesey visits Jim after the boy has been captured by pirates. Jim finds himself "ashamed to look him in the face" (164), but what exactly is he ashamed of? Is it simply that he has caused trouble for his friends by being caught, or that, as Silver warned, he will appear to have betrayed them? Within the order of the play ethic, it hardly matters that Jim has done nothing morally blameworthy or that his intentions were heroic. It matters only that his position looks bad to Livesey, and it is the doctor's opinion, not his own motives, that count. In Stevenson's story, this flash of shame is little more than a passing moment of uneasiness, and Jim quickly redeems himself by his actions. But in the following decades of imperial adventure stories, the play ethic's emphasis on performance produced haunting shadows of potential failure in the eyes of others, a trend exemplified in A. E. W. Mason's extraordinary treatment of masculine shame among the soldiers of empire, The Four Feathers (1902). Still, the most illuminating analysis of shame as the characteristic anxiety of the play ethic is not Mason's novel but Conrad's Lord Jim. Conrad had seen enough of the adventure stories since Treasure Island to regard them suspiciously, even as he understood why boys and men might find them alluring. His ambivalent representation of youth and shame demonstrates how the play ethic forces on its players an intense strain of performance as they submit their identities to the observation of other men, even though such games may be impractical and delusional. He shows us, in short, the price of a childishly ludic approach to the imperial world, but, measuring that price against the often shabby or hypocritical strictures of moral maturity, asks whether it might be worth paying. 
Conrad's Jim, like Baden-Powell or Rhodes, is another of those late-Victorian imperial adventurers who never grow up. Indeed, Jim represents the quintessence of preserved youth, as Marlow indicates when he calls him "the youngest human being now in existence" (213). Raised on a diet of adventure stories like Stevenson's, Jim has a worldview determined by the play ethic: "ever since he had been 'so high'-'quite a little chap,' he had been preparing himself for all the difficulties that could beset one on land and water" (112). Life, in this persistently boyish estimation, is an adventurous game in which, provided the universe can be relied upon to respect the rules of fair play, one can test and prove oneself. From the opening chapter of the novel, which leaves Jim "angry with the brutal tumult of earth and sky for taking him unawares" and thus cheating him out of a chance of heroically saving a drowning man before a crowd of admiring shipmates (42), Jim expects the world to conform to the possibilities of the playground. Thwarted by his experiences but never disillusioned by them, Jim carries his dreams with him to the rough edge of the imperial frontier where, "three hundred miles beyond the end of telegraph cables and mail-boat lines, the haggard utilitarian lies of our civilization wither and die, to be replaced by pure exercises of the imagination" (264). On the fringe of empire, Jim finds the circumscribed playground for his game, including an improbably appropriate confrontation with a piratical nemesis, Gentleman Brown, according to rules Jim proposes. There he achieves what Marlow describes as his ultimate victory in this youthful game: "Not in the wildest days of his boyish visions could he have seen the alluring shape of such an extraordinary success!" (372). Jim's story, in Marlow's eyes at least, is a triumph within, and also of, the play ethic.

Yet Lord Jim also interrogates the adventure tradition in which Stevenson was so influential, and many critics have taken pains to distinguish it from the imperial romances that fascinate Jim, reading the novel as a rejection or deconstruction of that tradition. ${ }^{5}$ Despite Conrad's skepticism about Jim's juvenile dreams, however, Marlow makes a serious appeal to the novel's readers to acknowledge the attraction of his persistent boyhood. As Andrew Roberts has argued, Conrad's work generally reflects "a highly problematic sense of masculinity as fractured, insecure and repeatedly failing in its attempts to master the world" (3), but not all failures are equal for Conrad, and some problematic masculine styles, like some problematic imperial projects, are better than others. While we might assume that Jim's childish naiveté may count for little in 
Conrad's world of hard work and disillusionment, we should recall, as Kenneth Simons has argued, that Conrad's texts are saturated with references to play and youth. The stubbornly immature Jim might begin as a figure of ridicule and pity, but by the end of the novel Marlow has found much to affirm in the boyish code that guides him, and in the play ethic as an arena for the assertion of individual identity.

It is certainly true that Marlow finds something distasteful in the gross immaturity of Jim's reaction to his crime aboard the Patna: "You had to listen to him as you would listen to a small boy in trouble. He didn't know. It had happened somehow. It would never happen again" (126). There is a shade of mockery in Marlow's description of Jim's childish lack of moral reflection, his eagerness to imagine his next test rather than dwelling on the consequences of deserting his ship. If Jim's response to the Patna incident seems morally insufficient, it is because Jim, like his predecessors in Treasure Island, does not understand his actions within the discourses of guilt, self-criticism, and sin that had been more characteristic of mid-century fiction. Jim thinks instead in terms of shame, that is, of his failures as they appear to others. Thus, the problem of the Patna, for Jim, has nothing to do with the people he might have endangered-a consideration that would have been driven by guilt or conscience-but with his own identity as constituted through the actions he performs for witnesses, and with the possible reconstitution of that identity, not by making amends but by performing once again. In this rough distinction between guilt and shame, the former represents the sanction of conscience according to internalized laws of right and wrong and the latter the external sanction of a group concerned primarily with behavior rather than motive. ${ }^{6}$ Admittedly, no ideological formation is wholly reliant on either guilt or shame, but the distinction does underscore a growing emphasis on shame in late-Victorian constructions of male behavior.

Just as on the playground a boy must be constantly aware of other boys' keen gazes, Conrad's Jim must submit himself to the scrutiny of other men, to stand "elevated in the witness box, with burning cheeks," suffering "the shame that made you burn, the attentive eyes whose glance stabbed" (58). Jim's trial is important enough to dominate the first half of the novel, yet in its own juridical terms it is almost entirely superfluous; if anything, the trial dramatizes the relative meaninglessness of legal guilt and of moral culpability. What matters to Jim, to Marlow, and to the thematic structure of the novel is Jim's 
recognition that the collective interpretation of all the men who see his trial or hear his story will do more to define him than any of his private feelings. The play ethic demands that he be prepared to endure the public sanction of shame if he is to maintain his dream of glory.

Conrad's novel is as much preoccupied with the masculine conventions of shame and honor as are its protagonists, though Conrad is characteristically skeptical of these values even as his story helps sustain them. Marlow is initially bothered that Jim "made so much of his disgrace while it is the guilt alone that matters" (178), though he, too, worries far more about Jim's reputation than his morality. Although Marlow never ceases to grope after some transcendent principle with which masculine identity might be fixed-"its secret truth, its hidden reality" (52) - the comforts of metaphysics remain elusive, as do those of the old institutions: neither the church, nor the court, nor the family offers the characters in this novel any secure sense of masculine identity to cling to in defiance of the opinions of their peers. There are only the collective standards of masculine groups-temporary, mercurial, interpretable rules based on nothing absolute, but nevertheless necessary and authoritative. Marlow's understanding of the simultaneous necessity and arbitrariness of the rules explains his ambivalence about Jim's attempt to define himself:

\footnotetext{
It was solemn, and a little ridiculous too, as they always are, those struggles of an individual trying to save from the fire his idea of what his moral identity should be, this precious notion of a convention, only one of the rules of the game, nothing more, but all the same so terribly effective. (101, emphasis added)
}

Marlow is not unlike Jim in realizing that identity must be acted out according to provisional rules and affected roles. But because his double view of those rules highlights their ridiculousness as well as their authority, Marlow provides what few other characters in the tradition of imperial romance can: a clear expression of the frustrations and anxieties of experiencing manhood under this code. He can tell us, for instance, of the peremptory power of even the most absurd games of masculine honor, such as the misunderstanding that nearly drives him and Jim to blows outside the courthouse, a contest that, despite the vacuity of its cause and the lack of personal animosity on either side, grows inevitable because of the rules both men recognize (92-96). Without the liberal fantasy of self-validation, the players of this game constantly seek the affirmation of other men, and they live 
in fear of being misunderstood. Jim can never be happy self-sufficiently, and Marlow cannot rest without assurances that others understand and appreciate Jim, too.

Shrewd readers of Conrad have analyzed his attitude toward imperialism in terms not of unqualified acceptance or contempt but of his preference for particular forms of imperial action associated with particular masculine codes over other forms he regards as base or unmanly. Critics such as John Kucich and Andrew Roberts have stressed Conrad's vindication of maritime professionalism, but their readings of Conrad's oeuvre need to be qualified in the case of Lord Jim, which, with its fixation on Jim's youthfulness and the romance tradition to which he is bound, challenges the ethos of maritime professionalism by comparing it to the play ethic. Hence Conrad gives us Captain Brierly, who, before his surprising suicide, represents the pinnacle of professional success. Brierly is critical of the cluster of values Jim instantiates, and objects to Jim's decision to stand trial as an affront to "dignity" and "professional decency" that will bring "infernal publicity" to the sailors: "We aren't an organized body of men, and the only thing that holds us together is just the name for that kind of decency" (90-91). Brierly's professionalism shares many features with the play ethic, especially its keen awareness of shame and reputation as well as its emphasis on maintaining a good name rather than a morally pure heart; like Jim, Brierly is unconcerned with the moral consequences of the Patna desertion for its pilgrim passengers (91). But for Brierly, the salient unit of identity is the group rather than the individual, and he would rather see Jim abscond from the trial, as had his detestable shipmates, to preserve the honor of the profession. Jim's courageous submission to the scrutiny of other men-a courage which Marlow, unlike Brierly, begins to appreciate as a "redeeming feature" (91) - claims a space for individual heroism within the shared order of the play-community. Brierly's disdain for the individual performance at the expense of collective reputation leaves room only for lesser virtues such as reliability and uncomplaining efficiency, the mechanical virtues symbolized by his gold chronometer. The inability of these values to sustain a man is suggested by Brierly's suicide, and by the pathetic postscript to his career, which reveals that he has vastly overestimated the esteem in which he was held by his corporate masters (86).

In Conrad's greatest concession to the play ethic, the climax of his novel turns precisely on the rules of Jim's own game: an agonistic 
struggle against a worthy adversary, the "latter day buccaneer" Gentleman Brown. Marlow's presentation of Brown is vexed from the start. On one hand, he is quick to deflate the romantic associations of piracy, dismissing pirates generally as mere "ruffians," and introducing Brown writhing on his ignominious deathbed, where he chokes out his story between fits of coughing. But Marlow also distinguishes between "merely vulgar and greedy brutes" and Brown, who is "moved by some complex intention" (320). The complexity of Brown's motivation turns out to be a darker version of Jim's own: Brown does not simply want to loot Patusan, but to "play havoc with that jungle town that had defied him" (337), and all of his actions are driven by a desire for vengeance against foes whom he regards as having dishonored him. Like Jim, he is driven by shame and reputation, just as eager to tell how he defeated Jim as Marlow has been to explain how Jim triumphed in the end. Brown's gloating reminds us of Jim Hawkins's mockery of Israel, Stalky's ritualistic taunting, or Peter Pan's endless crowing, because Brown, too, is a child of the play ethic, in which victory counts only when performed and acknowledged.

Marlow is so invested in interpreting the clash of Jim and Brown as a game of honor that he treats it as "the deadliest kind of duel" (349), a form of competition that Huizinga regards as among the most quintessential expressions of play. Brown's canny attempts to persuade Jim of their similarities-their shared race, their shared experiences and precepts-comprise the bulk of their confrontation. Once Jim recognizes Brown as a comparable sort of man, as the kind with whom he can deal according to the rules, he offers the pirate a choice dictated by the practice of fair play: "a clear road or else a clear fight” (351). True to form, he refuses to judge Brown on moral grounds, so that when Jewel asks whether the pirates are bad men, he answers, "Men act badly sometimes without being much worse than others" (356). Jim would give Brown exactly what he thinks he himself deserves, a chance to restore his prestige, and he thus fails to recognize that Brown's egotism demands not redemption but revenge. Brown, enraged at the slight he perceives in Jim's unwillingness to fight, takes out his anger by slaughtering Jim's Bugis comrades, and it is at this point that Marlow interrupts with a surprisingly sympathetic apology for Brown's attack: "Notice that even in this awful outbreak there is a superiority as of a man who carries right-the abstract thing-within the envelope of his common desires. It was not a massacre; it was a 
lesson, a retribution" (363). "Notice," Marlow instructs his reader, anxious that the meaning of Brown's gesture is not misinterpreted as mere viciousness or moral outrage. Marlow recognizes that Brown's audacity, like Jim's, exalts him beyond "common desires," and he is willing to affirm that, according to the standards of play, this awful act constitutes a kind of victory. Just as Marlow approves Jim's final, suicidal performance as an "extraordinary success," he reports-and endorsesBrown's deathbed scene as a "triumph in articulo mortis" (347): "I can testify that he had played his part to the last" (364).

Marlow finishes by testifying for Jim, too, praising "his eternal constancy," and reiterating that "He is one of us." But the meaning and worth of Jim's last gesture can be determined only by those like him, those in a position to appreciate his adherence to a "shadowy ideal of conduct" (372). He cannot be interpreted according to the usual codes-yet as is typical on the playground, the limited and esoteric qualities of the rules serve to strengthen the bonds of the players, to intensify the feeling of communal identity. As Huizinga writes, "Even in early childhood the charm of play is enhanced by making a 'secret' out of it. This is for us, not for the 'others'. What the 'others' do 'outside' is no concern of ours at the moment. Inside the circle of the game the laws and customs of ordinary life no longer count" (12). The final function of Marlow's refrain-Jim is "one of us"-is not merely to allude to some existing group to which Jim belongs, but to constitute a collective "us" around the figure of Jim. The novel interpellates its readers, inviting us to think of ourselves as those who understand Jim and share the values that drive him. We could even view the novel as asking us to play with Jim.

In asking its readers to appreciate the triumph of Jim's boyish adventure, the novel does not demand support for the imperial project in any practical sense. Indeed, practicality is beside the point insofar as the consequence of thoroughgoing imperialism - especially according to the liberal, developmental model of the civilizing mission-would be to entangle places like Patusan in a modern web of telegraph lines and mail-boat routes, and thus spoil them as autonomous realms of play. Lord Jim's imperialism is necessarily nostalgic. It looks back wistfully to a golden age of piratical traders who would "cut each other's throats without hesitation" (219), and to adventurers like James Brooke, the White Rajah of Sarawak, whose rather piratical exploits in Jim's Malaysian stomping grounds were the object of Conrad's own "boyish 
admirations" (Letters 210). But though the days of these great men have slipped away, Conrad suggests, something of their greatness might still be felt by any man who recognizes their aspirations in the memories of his own youth. Lord Jim upholds an imperialism of the masculine spirit, indirectly encouraging men to accept the competitive, self-aggrandizing politics of conservative imperialism as congruent with the natural impulses of boyish dreams.

\section{Conclusion: The Pirate Empire}

The examples of Treasure Island and Lord Jim suggest that the waning influence of the teleological imperatives of liberal imperialism were supplanted by new fantasies of power that were at once nondevelopmentally ludic (and thus forever boyish) and amorally competitive. The novels, though, express these fantasies within a literary tradition of pirate stories-a tradition that Stevenson subversively redirected and that Conrad examined with mingled concern and nostalgia-in which the influence of new imperial ideologies is mediated by its representation through the accumulated tropes of the genre. We should not expect, therefore, that the terms in which these fantasies are couched in fiction should be identical to those in which they are expressed in formal political or legal discourse, any more than we should regard Long John Silver simply as Disraeli with a peg leg. Nevertheless, history offers some moments of striking discursive alignment in which the architects of imperial policy, the instruments of imperial power, and the fabulists of imperial romance speak in roughly the same language, when we can infer not only their mutual influence, but also the underlying ideological pressures that shaped them all. The most illustrative of these moments arose during the second Anglo-Boer War (1899-1902), the time of Britain's most extensive military mobilization since the Napoleonic Wars and of its most intense imperial fervor since the Indian rebellion. It was also the moment at which Britain was accused of having become a pirate empire.

The charge of imperial piracy was most famously leveled by the Liberal leader John Morley, whose characterization of Britain's "pirate empire" in an 1899 speech was widely reported: "What a farce, what an example for this country which has hitherto vaunted and boasted-and justly boasted-that it is the font of great moral, pacific, and progressive causes!... What a shadow cast upon the reign of the 
Queen! Yes, empire, they say-empire. Yes, but we do not want a pirate empire" (qtd. in Harding 354). Morley invokes piracy not only to bemoan what he regards as the abandonment of the principles of morality and progress, but also to decry what he takes to be Britain's violation of international law. By waging war against the Boer republics of the Transvaal and the Orange Free State, Britain would be breaking its own treaties, specifically the Pretoria Convention of 1881 and the London Convention of 1884, both of which affirmed Boer control over the domestic policies of their nations. Morley's accusation was echoed and amplified in the Westminster Review by W. J. Corbet, who argued that the "pirate empire" had launched "an unjust, immoral, unprovoked, and most sanguinary war" against states "whose independence was supposed to be forever safeguarded and secured by treaties solemnly entered into, signed, sealed, and delivered, under the sanction of her Majesty Queen Victoria” (477). Both Morley and Corbet, then, draw on the old juridical definition of pirates: hostes humani generis who operate outside the law of nations.

Morley and Corbet's liberal complaints about the empire's piratical lawlessness represent what had become a minority position that, at least during the war, did not sway either policy or popular sentiment. Indeed, other contemporary arguments were just as effectively piratical, and almost as openly so, as the liberals alleged. When, for instance, John Westlake, professor of international law at Cambridge, defended Britain's entry into the war, he announced that in this case, the justification must be sought "outside the law" (21), in a "higher justice" (6). One might wonder what sort of justice Westlake, a legal scholar after all, might take as higher than international law, but he leaves the issue ambiguous, much as Marlow does in attributing to Jim "a faith mightier than the laws of order and progress" (308). But more importantly, Westlake regards the Boer problem as "one of those situations" that reveal the limitations of legality as a general principle in the conduct of imperial policy, contending that Salisbury's government would be best served by avoiding the question of law altogether. This is not so much a rebuttal to Morley's charge of piratical disregard for the law of nations as an assurance that, in certain situations, piracy is the correct approach to empire.

The appeal of an explicitly piratical play ethic can also be traced in the actual battlefields of the Transvaal, where it was expressed by scouts and irregular mounted troops from across the barely 
civilized colonial frontiers (see MacDonald 80). But the piratical glamor surrounding the scouts had only partly to do with the skull and crossbones badges some of them favored; they also disdained the usual imperatives of drill and other forms of collective discipline, bringing improvised guerilla tactics to bear against the insurgent Boer commandos, who were likewise associated with-and often admired for-wily ruses and individual skill. Together, the Boers and British scouts were celebrated for spontaneously constituting a play-community structured by its own rules rather than by traditional military regulations that had directed soldiers to stand in formation and fire volleys, or by an athletic games ethic that would emphasize their moral discipline and teach them to disdain the treacherous strategies that won them renown.

Not long after, Baden-Powell turned to these same Boer War scouts for a model of masculinity that could appeal directly and powerfully to the boys of the empire, a model that could be experienced through the spirit of competitive play with which Scouting for Boys (1908) is thoroughly infused. Play acting, dressing up in disguises, pretend manhunts, games of observation and memory: such are the diverse forms of boyish play that-even more than athleticism-form Baden-Powell's project to guarantee the empire's future. Yet the future would look much like the present. The colonies were to be maintained rather than civilized, as were the agents who secured them. As Elleke Boehmer points out, Baden-Powell's vision of play "aims to forestall for ever the process of growing up" (xxvi).

Two years after the Boer War, the most famous of the boys who never grew up made his debut on the London stage. Barrie's Peter Pan is born of late-Victorian conceptions of competitive child's play and of the adventure stories in which they were popularized. Peter Pan embodies these ideas so richly and convincingly that he has come to stand for a transcultural and transhistorical archetype: the puer aeternus. But Peter Pan, seductive and cruel, ludic and lawless, as ready to trade places with Captain Hook as to fight him, is entirely a figure of his time. He lives on a playground where the endless, circular struggle of lost boys, pirates, and redskins means nothing except for the pleasure of play. The boyishness he epitomizes, linked as it is with a piratical disregard of legal or moral restraint, was neither frivolous nor harmless. It bears real responsibility, in Arendt's words, "for crimes committed in the spirit of play, for the combination of horror and 
laughter" (190). It represents a crucial reformulation of the ethical order of imperialism and its intersection with masculine identity, an enlivening dream of manhood reconstituted as the exhilarating play of clever and heartless boys in empire's great game.

University of Minnesota, Morris

\section{NOTES}

${ }^{1}$ For a broad overview of the many competing rhetorics of play, see SuttonSmith. Matthew Kaiser has recently adapted Sutton-Smith's taxonomy to demonstrate the complexity of play in Victorian thought.

${ }^{2}$ See, for example, Groos 400 and Cook 4.

${ }^{3}$ While several characters-Trelawney, for instance-decry the immorality of piracy, the novel routinely reveals their complicity in the behaviors they criticize. Likewise, the Christian moral framework that had previously governed the pirate encounters of juvenile literature are nearly absent here, so that religion becomes laughably irrelevant.

${ }^{4}$ For Treasure Island's influence on later pirate stories, see Carpenter 83-90.

${ }^{5}$ For more on the complicated relationship of Conrad to the popular adventure tradition, see White; Dryden; Gasiorek.

${ }^{6} \mathrm{I}$ borrow this distinction between guilt and shame from a twentieth-century anthropological tradition inaugurated by Ruth Benedict, but there are similar distinctions evident in Victorian culture, as in Darwin's The Expression of Emotions in Man and Animals (see Chapter 13).

\section{WORKS CITED}

Arendt, Hannah. The Origins of Totalitarianism. San Diego: Harcourt, 1968.

Baden-Powell, Robert. Scouting for Boys. 1908. Ed. Elleke Boehmer. Oxford: Oxford UP, 2004.

Ballantyne, R. M. The Coral Island: A Tale of the Pacific Ocean. 1857. London: T. Nelson, 1884.

Barrie, J. M. Peter Pan in Kensington Gardens; Peter and Wendy. Oxford: Oxford UP, 1991.

Benedict, Ruth. The Chrysanthemum and the Sword: Patterns of Japanese Culture. Boston: Houghton Mifflin, 1946.

Bivona, Daniel. British Imperial Literature, 1870-1940: Writing and the Administration of Empire. Cambridge: Cambridge UP, 1998.

Boehmer, Elleke. Introduction. Baden-Powell, xi-xxxix.

Boys and Their Ways, By One Who Knows Them. London: James Hogg, 1880.

"B-P, Our Chief of Boys." The Children's Newspaper (16 June 1934): 8.

Bristow, Joseph. Empire Boys: Adventures in a Man's World. London: Harper, 1991.

Carpenter, Kevin. Desert Isles and Pirate Islands: The Island Theme in Nineteenth-Century English Juvenile Fiction. Frankfurt: Verlag, 1984.

Conrad, Joseph. Joseph Conrad's Letters to R. B. Cunninghame Graham. Ed. C. T. Watts. Cambridge: Cambridge UP, 1969. 
—. Lord Jim. 1900. Ed. Cedric Watts. Peterborough: Broadview, 2001.

A Set of Six. 1908. New York: Doubleday, 1923.

Cook, H. Caldwell. The Play Way: An Essay in Educational Method. New York: Frederick A. Stokes, 1917.

Corbet, W. J. "A Pirate Empire: The Policy of Grab." Westminster Review 156.5 (Nov. 1901): 477-89.

Darton, F. J. Harvey. Children's Books in England: Five Centuries of Social Life. 3rd ed. London: British Library, 1999.

Darwin, Charles. The Expression of Emotion in Man and Animals. 1872. New York: Appleton, 1898.

Dickens, Charles. "The Perils of Certain English Prisoners." 1857. The Works of Charles Dickens. Gadshill Ed. Vol. 31. London: Chapman and Hall, 1898. 191-247.

Doyle, Arthur Conan. The Green Flag and Other Stories of War and Sport. New York: McClure, 1900.

The Lost World. New York: A. L. Burt, 1912.

Dryden, Linda. Joseph Conrad and the Imperial Romance. New York: St. Martin's, 2000.

Esty, Jed. "The Colonial Bildungsroman: The Story of an African Farm and the Ghost of Goethe." Victorian Studies 49.3 (2007): 407-30.

Forster, E. M. "The Boy Who Never Grew Up.” Daily Herald 9 June 1920. 7.

Gasiorek, Andrzej. "'To Season with a Pinch of Romance': Ethics and Politics in Lord Jim." Conrad and Theory. Ed. Andrew Gibson and Robert Hampson. Amsterdam: Rodopi, 1998. 75-112.

Griffith, George. Men Who Have Made the Empire. 1897. London: C. Arthur Pearson, 1899.

Groos, Karl. The Play of Man. Trans. Elizabeth L. Baldwin. 1901. New York: Appleton, 1919.

Haggard, H. Rider. King Solomon's Mines. 1885. Peterborough: Broadview, 2002.

Harding, William. War in South Africa and the Dark Continent from Savagery to Civilization. Chicago: H. L. Barber, 1899.

Hobson, J. A. Imperialism: A Study. 1902. Ann Arbor: U of Michigan P, 1965.

Huizinga, Johan. Homo Ludens: A Study of the Play Element in Culture. Boston: Beacon, 1955. Hyne, C. J. Cutcliffe. Adventures of Captain Kettle. New York: G. W. Dillingham, 1898.

Kaiser, Matthew. "The World in Play: A Portrait of a Victorian Concept." New Literary History 40.1 (2009): 105-29.

Kingsley, Charles. Westward Ho! or, the Voyages and Adventures of Sir Amyas Leigh, Knight. Cambridge: Macmillan, 1855.

Kingston, William H. G. The Pirate of the Mediterranean. London: Thomas Cautley Newby, 1851.

Kipling, Rudyard. The Complete Stalky Ev Co. 1899. Oxford: Oxford UP, 1999.

—. Kim. 1901. New York: Penguin, 1989.

Kucich, John. Imperial Masochism: British Fiction, Fantasy, and Social Class. Princeton: Princeton UP, 2007.

MacDonald, Robert H. Sons of the Empire: The Frontier and the Boy Scout Movement, 18901918. Toronto: U of Toronto P, 1993.

Maixner, Paul, ed. Robert Louis Stevenson: The Critical Heritage. London: Routledge, 1981. 
Mangan, J. A. The Games Ethic and Imperialism: Aspects of the Diffusion of an Ideal. New York: Viking, 1986.

Mason, A. E. W. The Four Feathers. 1902. Ed. Gary Hoppenstand. New York: Penguin, 2001. Menpes, Mortimer, and Dorothy Menpes. War Impressions. London: Black, 1901.

Nadel, Ira Bruce. "'The Mansion of Bliss,' or the Place of Play in Victorian Life and Literature.” Children's Literature 10 (1982): 18-56.

Noyse, Alfred. Drake: An English Epic. 1908. New York: Frederick A. Stokes, 1909.

Parker, Louis N. Drake: A Pageant Play. London: John Lane, 1912.

Pemberton, Max. The Iron Pirate. London: Cassel, 1893.

Rediker, Markus Buford. Villains of All Nations: Atlantic Piracy in the Golden Age. Boston: Beacon, 2004.

Roberts, Andrew Michael. Conrad and Masculinity. New York: St. Martin's, 2000.

Rose, Jacqueline. The Case of Peter Pan, or The Impossibility of Children's Fiction. London: Macmillan, 1984.

Sabatini, Rafael. The Sea Hawk. 1915. Washington: Regnery, 1998.

Simmons, Diane. The Narcissism of Empire: Loss, Rage and Revenge in Thomas De Quincey, Robert Louis Stevenson, Arthur Conan Doyle, Rudyard Kipling, and Isak Dinesen. Brighton: Sussex Academic, 2007.

Simons, Kenneth. The Ludic Imagination: A Reading of Joseph Conrad. Ann Arbor: UMI Research, 1985.

Spencer, Herbert. Principles of Psychology. 1880. 2 vols. New York: Appleton, 1883.

Stevens, Charles. Jack Rushton; or, Alone in the Pirates' Lair. 1866-67. London: E. J. Brett, 1870.

Stevenson, Robert Louis. "To Cosmo Monkhouse." 16 March 1884. The Letters of Robert Louis Stevenson to His Family and Friends. Ed. Sidney Colvin. Vol. 1. New York: Scribner's, 1900. 364-67.

—. Treasure Island. 1883. Ed. John Seelye. New York: Penguin, 1999.

—. Virginibus Puerisque. 1881. New York: Current Literature, 1910.

Suleri, Sarah. The Rhetoric of English India. Chicago: U of Chicago P, 1992.

Sutton-Smith, Brian. The Ambiguity of Play. Cambridge: Harvard UP, 1997.

Thorndike, Russell. Doctor Syn: A Smuggler Tale of Romney Marsh. New York: Doubleday, 1915.

Westlake, John. The Transvaal War. London: C. J. Clay, 1899.

White, Andrea. Joseph Conrad and the Adventure Tradition: Constructing and Deconstructing the Imperial Subject. Cambridge: Cambridge UP, 1993. 